Handep, Jurnal Sejarah dan Budaya Vol. 3, No. 1, Desember 2019, hlm. 1-32

\title{
GUGUNG DAN JEHE: PEMBELAHAN ETNIK KARO DI SUMATRA UTARA
}

\author{
GUGUNG $A N D$ JEHE: \\ THE CLEAVAGE OF KARO ETHNIC IN NORTH SUMATRA
}

\author{
Erond L. Damanik \\ Universitas Negeri Medan \\ Jln. Willem Iskandar Pasar V, Medan, 20221, Sumatra Utara, Indonesia \\ eronddamanik@yahoo.com
}

Diterima tanggal 19 Februari 2019

Disetujui tanggal 5 Agustus 2019

\begin{abstract}
This study aimed to understand the cleavages of Karo ethnic in North Sumatra. It formulated the question: how was the cleavages of Karo ethnic carried out during colonial period? The paradigm of this study was ethnohistory with a mixed epistemological approach that combines historical, cultural anthropological, and archeological approaches to examine historical and cultural processes that give rise to ethnic cleavages. The research was carried out qualitatively. It can be concluded that the cleavages of Karo ethnic was a phenomenon of identity construction during colonial period, which was based on sociogeographical and socio-cultural differences with political, economic and social emphasis. Two social units resulting from cleavage, Karo Gugung and Karo Jehe, do not produce deep-rooted ethnic boundary because both of them still recognise the same objective attributes. The novelty of this study shows that ethnicity is a tool for forming new colonies which are subject to the Colonial Government.
\end{abstract}

Keywords: ethnic cleavages, Karo, Gugung, and Jehe.

\begin{abstract}
ABSTRAK
Studi ini bertujuan untuk memahami pembelahan etnik Karo di Sumatra Utara. Masalah dirumuskan pada pertanyaan: bagaimanakah pembelahan etnik Karo dilakukan selama periode kolonialisme? Paradigma yang digunakan pada kajian ini adalah sejarah etnik dengan pendekatan mixed epistemologi, yakni menggabungkan pendekatan sejarah, antropologi budaya, dan arkeologi untuk menelaah proses sejarah dan budaya yang memunculkan pembelahan etnik. Penelitian dijalankan secara kualitatif. Dapat disimpulkan bahwa pembelahan etnik Karo merupakan fenomena pengontruksian identitas selama periode kolonialisme, yang didasarkan pada perbedaan sosio-geografis dan sosiokultural dengan penekanan secara politis, ekonomi, dan sosial. Satuan sosial hasil pembelahan, yakni Karo Gugung dan Karo Jehe, tidak menghasilkan deep-rooted ethnic boundary karena keduanya masih mengakui atribut objektif yang sama. Kebaruan kajian ini bahwa etnisitas adalah alat pembentukan koloni baru yang tunduk pada Pemerintah Kolonial.
\end{abstract}

Kata kunci: pembelahan etnik, Karo, Gugung, dan Jehe. 
Handep Jurnal Sejarah dan Budaya Vol. 3, No. 1, Desember 2019, hlm. 1-32

\section{A. PENDAHULUAN}

Orang Karo di Sumatra Utara mengalami pembelahan berupa pembedaan dan pemisahan di internal etniknya. Pembelahan ini memunculkan dua satuan etnik Karo, yakni Karo Gugung yang bermukim di pegunungan dan Karo Jehe yang bermukim di dataran rendah. Karo Gugung dikategorikan sebagai orang Batak, sedangkan Karo Jehe adalah orang Melayu (Perret, 2010). Permukiman Karo di pegunungan (gugung) disebut Tanah Karo Simalem, sedangkan di dataran rendah (jehe) disebut Tanah Melayu. Pembelahan ini juga merasuk hingga ke pemerintahan tradisionalnya, dengan munculnya sebutan sibayak (di Gugung) dan kesultanan (di Jehe). Gugung disebut uncivilized, yakni kolektivitas masyarakat yang pagan, liar bahkan antropopagi. Sebaliknya, Jehe disebut civilized, yakni kolektivitas masyarakat yang mencerminkan keberadaban (Hirousue, 2009: 192). Kedua satuan etnik hasil pembelahan ini diberi identitas khusus sebagai kesadaran pemersatu. Keseluruhan pembelahan ini terjadi pada periode kolonialisme sebagai proses sejarah dan budaya dalam kerangka penaklukan.

Artikel ini bermaksud untuk meninjau dan memahami fenomena pembelahan etnik Karo selama periode kolonialisme. Fenomena pembelahan etnik ini dipandang sebagai gejala konstruktif (Hale, 2004: 458), bukan gejala primordial (Geertz, 1963: 105). Hale berpendapat bahwa etnisitas sangat dinamis, cair, dan rentan dimanipulasi sesuai situasi etnisitas (ethnicity situation) yang mengitarinya (Royce, 1983; Glazer, 1963; Barth, 1969; Francis, 1976; Naroll, 1964). Pernyataan ini berbeda dengan perspektif primordial yang memandang etnisitas sebagai kolektivitas masyarakat yang terikat atribut-atribut primordial, seperti bahasa, agama, teritorial, dan kultural (Geertz, 1963: 105; Shils, 1954: 130). Menurut pandangan ini, etnisitas dilihat sebagai identitas yang given, askriptif, dan alamiah.

Paradigma konstruktif melihat etnisitas bukanlah gejala yang statis, given atau askriptif, melainkan cenderung berubah sesuai situasi etnisitas yang mengelilinginya. Pengontruksian suatu satuan etnik sangat bergantung pada pelaku-pelaku sosial untuk menerima ataupun menyangkal identitasnya pada saat berhadapan dengan pelaku sosial lainnya (Hale, 2008: vii; Barth, 1969: 78). Dalam hal ini, pernyataan "kemantapan strategis etnik" (Glazer, 1963: viii) ataupun "permainan etnik" (Berghe, 1981: 57) mencerminkan kedinamisan dan cairnya etnisitas itu. Fenomena penerimaan dan penyangkalan etnisitas bergerak sesuai situasi etnisitas yang sangat dipengaruhi oleh akses ke sumber daya material, sosial, ekonomi dan politik (Royce, 1983: 210; Glazer, 1963: xi). Jadi, etnisitas adalah alat untuk meraih dan menguasai sumber daya sosial (Hale, 2004).

Fenomena pembelahan etnik 
sangat dimungkinkan terjadi selama periode kolonialisme karena terkait dengan peluang sosial, khususnya aspek politik dan ekonomi. Fenomena ini dapat dipandang sebagai bagian dari strategi adaptasi dan mempertahankan kesinambungan sosial dan kultural dengan cara meraih peluang-peluang sosial yang ada (Berghe, 1981: 52). Cara pandang seperti inilah yang dipergunakan untuk melihat dan memahami fenomena pembelahan etnik Karo di Sumatra Utara.

Asumsi teoretik pada kajian ini adalah pembelahan etnik Karo menjadi dua satuan etnik, yaitu Karo Gugung dan Karo Jehe, diperkirakan berkaitan dengan faktor sosio-geografis dan sosiokultural. Kedua faktor utama ini tidak dapat dipisahkan dari proses penaklukan yang terjadi selama periode kolonialisme. Masing-masing satuan etnik yang dibentuk memiliki kepentingan untuk mengakses sumber daya material, ekonomi, politik, sosial, dan budaya. Adapun rumusan masalah yang ingin dijawab pada studi ini adalah bagaimanakah etnik Karo mengalami pembelahan selama periode kolonialisme?

Permasalahan tersebut ditelaah dengan menggunakan paradigma sejarah etnik (ethnohistory) dengan pendekatannya yang interdisipliner untuk menjelaskan dan memahami proses sejarah dan budaya yang berhubungan dengan terjadinya pembelahan etnik selama periode kolonialisme. Pendekatan interdisipliner merupakan mixed epistemologi yang menggabungkan pendekatan sejarah, antropologi budaya, dan arkeologi (Strong, 2015: 192-195). Pendekatan ini bermanfaat dalam menelaah proses munculnya pembelahan etnik. Adapun pembahasan mengenai Batak dan Melayu yang terdapat pada artikel ini dikaitkan dengan dikenalnya istilah Batak Karo untuk menamai satuan etnik Karo Gugung dan Melayu untuk Karo Jehe, yang bukti-buktinya didasarkan pada hasil pelacakan terhadap laporan para penjelajah sebelum periode kolonialisme.

Penting untuk disampaikan di sini, tatanan etnisitas di Sumatra Utara mencerminkan adanya campuran etnik eksplosif yang sangat berdampak dan berpotensi tinggi menjadi penyebab perpecahan, karena kondisi masyarakatnya yang plural dan multikultur (Geertz, 1982: iv). Misalnya, perpecahan di internal etnik Simalungun yang melahirkan orang Hataran dan orang Simalungun, atau di Tapanuli Tengah yang memunculkan etnik Pasisir. Bukan saja berkontribusi pada tingginya persaingan antaretnik, etnisitas yang ditandai oleh kontras keragaman etnik, agama, budaya, ideologi, dan kelas pun berpotensi menyebabkan konflik sosial (perpecahan). Selain itu, ketiadaan budaya dominan (dominant culture) akhirnya memberi keleluasaan bagi setiap etnik untuk mengembangkan identitas etniknya masing-masing serta menegasi identitas etnik (Bruner, 1981). 


\section{B. METODE}

Kajian ini menerapkan paradigma sejarah etnik (ethnohistory) yang merupakan kombinasi antara pendekatan sejarah, antropologi budaya, dan arkeologi. Fokusnya adalah pada proses budaya dan sejarah masyarakat (Strong, 2015: 194). Adapun sumber data yang digunakan adalah laporan perjalanan penjelajah; catatan dan laporan kolonial, seperti Memorie van Overgave $(\mathrm{MvO})$, mededeelingen, tijdschrift, bijdragen verhandelingen, verslag, maupun surat kabar, folklor, hasil kajian mengenai sejarah dan budaya masyarakat. Sumber-sumber yang bermanfaat sebagai bahan telaah awal tentang etnisitas ini memuat uraian tentang geografi, topografi, bahasa, agama, dan kebudayaan masyarakat. Sumbersumber ini berkontribusi pada penentuan atribut objektif dan subjektif kelompok etnik (Royce, 1983: xi). Catatan etnografi prakolonial dan di masa kolonial, folklor, maupun hasil kajian lintas disiplin tersebut dielaborasi menggunakan pendekatan sejarah etnik. Elaborasi dilakukan untuk memberikan perspektif yang tajam, analitis, dan diakronis tentang pengalaman dan perspektif masyarakat yang dikaji.

Secara khusus, pendekatan sejarah etnik yang digunakan adalah mixed epistemologis (Strong, 2015: 195), yakni pendekatan yang mengandalkan beragam mode penjelasan dan validasi, yang mengintegrasikan proses budaya secara makro dan mikro menjadi analisis yang koheren (Rogers, 1993: 63). Proses ini dilakukan untuk menemukan kontingensi sekaligus keberpihakan (Galloway, 2006: 42). Analisis dan interpretasi objektif serta mendalam pada sumber-sumber ini memberikan gambaran rinci tentang fenomena pembelahan etnik Karo. Melalui pendekatan ini, sumber-sumber tersebut dipilah-pilah sesuai kandungan isi (content) dan konteksnya.

Pendekatan mixed epistemologies melihat sejarah lisan sebagai bentuk pendekatan untuk membedakan antara waktu ekologis, waktu silsilah, kalender sosiologis (berulang), dan waktu peristiwa luar biasa (Vansina, 1985: 32). Pendekatan arkeologi berkontribusi pada akurasi penanggalan setiap archaeological evidence terkait asalusul, jejak perdagangan, sistem kehidupan sosial dan lain-lain, yang menggambar-kan peradaban manusia. Pendekatan antropologi bermanfaat menelaah karakteristik dan atribut kelompok etnik yang bersumber dari sejumlah laporan etnografi kolonial hingga pascakemerdekaan. Melalui cara itu ditemukan alasan, gejala, faktor, dan wujud yang menyebabkan adanya pembelahan etnik.

\section{HASIL DAN BAHASAN}

1. Historiografi dan LangkahLangkah Pembelahan

Upaya pemerintah kolonial membelah etnik Karo sangat dipengaruhi oleh peristiwa Perlawanan Sunggal (18721895). Perlawanan yang dipimpin Badiuzaman Surbakti terhadap Sultan 
Deli dan pemerintah kolonial mengakibatkan kerugian material bagi pengusaha perkebunan. Selain itu, Belanda memiliki kekhawatiran terhadap munculnya perlawanan yang lebih besar dan berkepanjangan, yang berdampak negatif bagi eksistensi perkebunan (Pelzer, 1988). Kekhawatiran ini cukup beralasan mengingat setelah itu muncul sejumlah perlawanan dari etnik Karo, di antaranya Kiras Bangun (1901-1904). Pada periode Pemerintah Militer Jepang, etnik Karo di Arhemia (Pancurbatu) melakukan Perlawanan Aron dengan maksud mengambil alih tanah-tanah perkebunan (Pemdasu, 1994: 87). Pada Agresi Militer I dan II terjadi perlawanan yang dipimpin Djamin Gintings, Selamat Ginting, dan Payung Bangun (Prima, 1976: 431; Pangdam II, 1997: 501). Jadi, etnik Karo memiliki riwayat perlawanan yang gigih terhadap kolonialisme ${ }^{1}$.

Perlawanan Sunggal dipicu kesewenang-wenangan Sultan Deli yang memberikan konsesi di wilayah Kedatukan Sunggal tanpa sepengetahuan Badiuzaman Surbakti sebagai Datuk Sunggal (Sinar, 1988;

${ }^{1}$ Di saat yang bersamaan, Pemerintah Belanda menghadapi sejumlah perlawanan yang dilakukan oleh etnik di luar Karo, seperti Rondahaim Garingging dari Raya Simalungun (1880-1891), Sang Na Ualuh Damanik dari Siantar Simalungun (1889-1906), serta Sisingamangaraja XII dari utara Tapanuli (1887-1907). Sejumlah perlawanan ini menimbulkan kecemasan yang tinggi bagi pemerintah kolonial karena dapat mengganggu eksistensi perkebunan.
Breman, 1997). Perlawanan secara bergerilya ini dilakukan dengan cara merusak tembakau dan membakar bangsal atau gudang (Erman, 2017; Veth, 1877; Schadee, 1919). Selain faktor pemberian konsesi tersebut, perlawanan juga dipicu karena hilangnya peran Datuk Sunggal dalam perdagangan opium, setelah diambil alih oleh Sultan Deli (Erman, 2017; Damanik, 2018).

Perlawanan ini menjadi embrio dari kecemasan pemerintah kolonial terhadap munculnya perlawananperlawanan dari etnik Karo yang lebih besar lagi. Asumsi seperti ini didasari oleh adanya realitas sosial bahwa etnik Karo di pegunungan memiliki ikatan kekerabatan dengan etnik Karo di dataran rendah, yang jika bersatu dikhawatirkan akan menimbulkan perlawanan yang lebih besar (Pelzer, 1988). Oleh karena itu, pemerintah kolonial berkepentingan untuk meredam perlawanan guna memberikan jaminan keamanan bagi para pengusaha perkebunan. Cara yang dipilih adalah memisahkan etnik Karo yang bermukim di pegunungan dengan yang di dataran rendah (Stoler, 1985). Selain untuk menjaga eksistensi perkebunan, faktor lain yang menjadi penyebab pemisahan etnik Karo adalah penemuan ladang minyak oleh Aeliko Janszoon Zijlker di tahun 1883. Ladang minyak tersebut berada di wilayah Karo Jehe, tepatnya di Telaga Said, Langkat (Ramadhan, 2008: 132).

Guna mereduksi perlawanan etnik Karo, garnisun militer dan kepolisian 
dibentuk di berbagai daerah di Sumatra Timur (Pangdam II, 1977). Pembentukan ini bersamaan dengan pemindahan ibu kota Karesidenan Sumatra Timur, dari yang semula di Bengkalis (Riau) kemudian beralih ke Medan, di tahun 1887. Garnisungarnisun militer dan kepolisian ini diharapkan dapat mereduksi perlawanan lokal terhadap Belanda (Langenberg, 1977; Reid, 1992; Prima, 1976; Pangdam II, 1977).

Setelah Datuk Sunggal “dibuang” ke Cianjur pada 1895, pembelahan etnik Karo yang dilakukan oleh pemerintah kolonial semakin tampak nyata (Sinar, 1988; Stoler, 1985; Perret, 2010). Pemerintah kolonial menugaskan Westenberg dan Joustra untuk menemukan basis dari pemisahan dan pembelahan etnik Karo tersebut. Di tahap awal, pemerintah kolonial melakukan pengerdilan wilayah geografis dengan membentuk daerah administratif yang tunduk pada pemerintah kolonial. Wilayah ini adalah Onderafdeeling Karolanden dengan ibu kotanya di Kabanjahe yang dibentuk sejak tahun 1906 dan dalam perkembangannya menjadi embrio Kabupaten Karo. Kemudian, di luar Onderafdeeling Karolanden ini, walaupun masyarakatnya dominan beretnik Karo tetapi dilepaskan dan digabung ke daerah administratif lainnya. Daerah-daerah dimaksud adalah Takengon, Baluren, Langsa, dan Bener Meriah yang disatukan ke wilayah Gayo, yakni Afdeeling Gayo en Alas (Brahmoputro, 1981; Pemdasu,
1994: 54). Wilayah lainnya adalah Langkat, Binjai, Medan, dan Tanjungmorawa yang dibentuk menjadi daerah administratif tersendiri. Daerah ini adalah Afdeeling Deli en Serdang, Gemeente Medan, Gemeente Binjai, dan Afdeeling Langkat (Singarimbun, 1975; Pemdasu, 1994: 54). Selain itu, wilayah Tanah Pinem, Tigalingga, dan Gunung Sitember dimasukkan ke wilayah Onderafdeeling Pakpaklanden. Sebagian wilayah Karo yang berbatas langsung dengan Simalungun dilebur menjadi wilayah Afdeeling Simalungun. Masing-masing daerah yang dipisahkan ini menjadi wilayah budaya (culture area) etnik Karo. Pengerdilan wilayah ini menyisakan wilayah Karo Gugung yang kemudian dikenal dengan Kabupaten Karo sekarang ini.

Penentuan batas-batas administratif era kolonial ini ditetapkan berdasarkan dua hal utama, yakni: (i) benteng alam, dan (ii) benteng budaya. Benteng alam ialah penentuan tapal batas yang mengacu pada kondisi lingkungan geografis, seperti sungai, hutan, dan gunung. Wilayah-wilayah yang secara geografis merupakan daerah perbukitan atau pegunungan dirangkum menjadi satu wilayah dan disebut gugung, sedangkan daerah landai (dataran rendah) ditetapkan menjadi beberapa wilayah yang disebut jehe. Karena alasan kepentingan ekonomi dan politik kolonial, wilayah jehe kemudian dibagi-bagi lagi menjadi beberapa satuan wilayah yang lebih kecil dan terpisah, seperti Langkat, Binjai, dan Medan. 
Di setiap wilayah administratif yang dibentuk tersebut ditunjuk seorang pemimpin zelfbestuur (pemerintah swapraja) yang tunduk kepada Belanda. Selain pejabat lokal, terdapat pejabat Eropa yang bertugas sebagai kontrolir (controleur) dan asisten residen, sebagai kepanjangan tangan dari Gubernur Keresidenan Sumatra Timur di daerah-daerah. Cara ini cukup efektif untuk mengendalikan dan mengawasi daerah-daerah, sehingga dapat mereduksi perlawanan rakyat. Pada setiap daerah administratif terdapat peradilan negeri maupun peradilan kerajaan (kerapatan) yang bertugas untuk menyelesaikan sengketa di antara inlanders atau kawula raja, tetapi tidak berhak mengadili orang Eropa.

Adapun yang dimaksud dengan benteng budaya adalah atribut sosial budaya yang dianggap mencerminkan tingkat peradaban (Joustra, 1910: 7; Westenberg, 1892: 54). Dalam hal ini, agama dianggap menjadi atribut utama peradaban yang digunakan sebagai basis pemisahan etnik Karo. Di masa itu, etnik Karo di gugung masih menganut kepercayaan asli yakni Pemena (Brahmoputro, 1981), sedangkan di jehe telah beragama Islam. Kedua satuan sosial yang dipisahkan ini dianggap berbeda karena memiliki perbedaan keyakinan. Benteng budaya, yakni agama Islam, juga menjadi dasar untuk mengelompokkan etnik Karo di Takengon, Baluren, Langsa, dan Bener masuk ke daerah Aceh. Etnik Karo di Tigalingga,
Pinem, dan Gunung Sitember yang masih menganut Pemena digabungkan ke Pakpak, karena kepercayaan ini dianggap sebagai varian dari agama Malim yang berkembang di utara Tapanuli (Joustra, 1910).

Jadi, pengerdilan wilayah etnik Karo dalam konsepsi penentuan tapal batas wilayah administratif ditentukan berdasarkan faktor lingkungan geografis dan budaya (agama yang dianggap sebagai instrumen utama peradaban). Pembedaan etnik Karo berdasarkan lingkungan geografis menghasilkan Karo Gugung dan Karo Jehe. Pembedaan sosiokultural etnik Karo berdasarkan agama yang dianut menghasilkan Batak Karo dan Melayu².

Langkah kedua dari pemisahan etnik Karo adalah pemberian isi atau karakter sebagai identitas dan kesadaran pemersatu. Dalam hal ini, upaya yang dilakukan adalah dengan cara mencari dan menentukan atribut sosial yang dianggap dapat mempersatukan setiap unit sosial yang telah dipisahkan itu. Atribut sosial yang menempel pada konsep Batak dan Melayu kemudian dipilih sebagai dasar untuk membedakan kedua unit sosial yang dibentuk. Citra Batak yang

\footnotetext{
${ }^{2}$ Penetapan tapal batas di era kolonial ini terus diacu hingga periode awal kemerdekaan Indonesia. Realitas ini terbaca dari penetapan daerah (kabupaten, kota, dan provinsi) di Sumatra Utara yang merupakan warisan administratif kolonial, dengan terbitnya UU Darurat No. 7 Tahun 1956 tanggal 14 November 1956 tentang Pembentukan Kabupaten Otonom di Provinsi Sumatera Utara (Pemdasu, 1994: 73).
} 
Handep Jurnal Sejarah dan Budaya Vol. 3, No. 1, Desember 2019, hlm. 1-32

diungkapkan dalam kata-kata yang merendahkan, misalnya uncivilized, disematkan pada etnik Karo di wilayah gugung. Penyematan ini sejalan dengan agama Pemena yang dianut oleh orang Karo Gugung dan dianggap pagan. Sebaliknya, citra Melayu yang dianggap kosmopolit dan civilized disematkan pada etnik Karo di wilayah jehe. Penyematan ini sejalan dengan agama Islam yang telah dianut mereka. Sebagai catatan, Islam telah berkembang di kalangan orang Karo Jehe sebelum periode kolonialisme (Moquette, 1922: 70).

Bagi pemerintah kolonial maupun bagi para penjelah di masa prakolonialisme, agama samawi dijadikan sebagai salah satu dasar untuk menentukan karakteristik masyarakat ke dalam dua golongan, uncivilized, dan civilized (Marsden, 2008). Masyarakat yang belum beragama samawi dianggap unicivilized, sedangkan masyarakat yang telah menganut agama samawi dianggap civilized. Pandangan ini dijadikan pedoman bagi pemisahan etnik Karo, sekaligus pemberi identitas baru sebagai pemersatu yang dibentuk dari luar. Etnik Karo penganut Pemena di gugung dikategorikan sebagai orang Batak Karo, sedangkan etnik Karo penganut agama Islam di jehe dikategorikan sebagai orang Melayu.

Lebih khusus bagi Batak Karo yang dianggap uncivilized societies ini kemudian dimediasi menjadi civilized societies melalui agama Kristen. Misi Zending Nederlandsch Zendeling Genootschap (NZG) mendapat tugas untuk menyebarkan agama Kristen pada etnik Karo di wilayah gugung. Penyebaran agama ini merupakan inisiatif J. Th. Cremer (Komisaris NV. de Deli Maatschappij dan anggota Parlemen Rendah di Belanda) yang dilakukan pascaredamnya Perlawanan Sunggal. Misi Zending NZG menunjuk J. H. Neumann dan mendirikan Pos Penginjilan di Buluh Awar (Sibolangit) pada 1890, yang kemudian dipindahkan ke Kabanjahe tahun 1902 (Perret, 2010). Misi ini pun mendirikan badanbadan zending seperti sekolah, rumah sakit, dan memberikan keterampilan hidup bagi masyarakat etnik Karo di gugung. Meskipun cara ini dianggap sebagai upaya "menanusiawikan manusia" (Neumann, 1902), namun tidak dapat dilepaskan dari proses sejarah dan taktik penaklukan.

Selain itu, pembangunan jalan raya yang menghubungkan Medan dengan wilayah gugung sejak tahun 1906, ataupun pembukaan beragam bungalo dan hotel di Brastagi, menjadi cara untuk membuka keterasingan orang Karo Gugung terhadap dunia luar. Melalui "modernisasi" ini, etnik Karo Gugung diharapkan tidak melakukan perlawanan terhadap Belanda. Kondisi yang berbeda terjadi di wilayah jehe. Intervensi terhadap agama Islam sama sekali tidak dilakukan oleh Belanda, kecuali "menjinakkan swapraja" dan melakukan modernisasi infrastruktur. Upaya ini dipilih untuk mendukung perkebunan dan pemerintahan selama periode kolonial. Sarana pendidikan dan kesehatan, misalnya, lebih 
difokuskan bagi pekerja (coelie) perkebunan. Faktor ini menjadi penyebab tidak munculnya tokoh-tokoh pemimpin di wilayah jehe, tidak seperti yang terjadi di gugung, yang bergerak pada ruang keagamaan dan pertanian. Masyarakat di wilayah jehe adalah kuli perkebunan (Jawa, India, Cina, dan indegenous ${ }^{3}$ lainnya) yang justru merasakan penderitaan yang luar biasa selama periode perkebunan kolonial (Said, 1977; Breman, 1997). Kemudian, penderitaan yang tidak ubahnya perbudakan ini memunculkan Poenale Sanctie (Dewi, 2004).

Identitas keagamaan sebagai kesadaran pemersatu menjadi taktik dan strategi ampuh menciptakan polarisasi etnik Karo di pegunungan (gugung) dan dataran rendah (jehe). Kedua satuan sosial ini menjadi terpisah dan setia kepada identitas barunya, yakni Batak Karo dan Kristen bagi orang Karo Gugung, serta Melayu dan Islam bagi orang Karo Jehe. Kesetiaan ini menjadi prasyarat yang mengindikasikan keberhasilan pembelahan dan pemisahan etnik Karo. Kenyataan ini merupakan wujud sentuhan modernitas yang dilakukan

3 Indegenous di Sumatra Timur, seperti Karo, Melayu, dan Simalungun, tidak diterima sebagai pekerja (coelie) di perkebunan. Kenyataan ini menurut Pelzer (1988) disebabkan karena tidak adanya kultur perkebunan pada masyarakat ini. Melayu, misalnya, dianggap pemalas dan sama sekali tidak cocok dipekerjakan di perkebunan. Kenyataan ini menjadi dasar bagi Nienhuijs untuk mengimpor pekerja dari Bagelan (Jawa Tengah), Penang, maupun India. pemerintah kolonial, pengusaha perkebunan, maupun Misi Zending (Hirousue, 2009; Perret, 2009; Damanik, 2017a; Hidayat dan Damanik, 2018; Damanik, 2017b; Damanik, 2018a). Promosi-promosi identitas baru ini terus dilakukan melalui produksi wacana modernitas dan pembedaan melalui pendidikan, pranata sosial, dan keagamaan, maupun surat kabar, seperti Tjermin Karo di Binjai dan Soeara Karo di Kabanjahe (Perret, 2010).

Langkah pemisahan etnik Karo berikutnya dilakukan melalui pengisian ruang sosial melalui aktivitas ekonomi. Wilayah jehe yang sejak tahun 1863 telah menjadi bagian dari wilayah penanaman (cultuurgebied ${ }^{4}$ ) kehilangan tanah-tanahnya, merasakan penderitaan, dan menjadi Rakyat Penunggu Tanah Jaluran (Agustono, 1997). Di Langkat, selain karena perkebunan, etnik Karo pun kehilangan tanah karena eksplorasi minyak bumi sejak tahun 1883. Meskipun perkebunan dan tambang minyak menjadi faktor modernisasi di wilayah jehe, tetapi juga menjadi pemicu penderitaan, penyakit, dan kesengsaraan. Namun, masyarakat di wilayah ini tidak bisa berbuat banyak karena kesultanan lebih bersimpati kepada pemerintah kolonial. Ikhsan, seorang penulis di Universitas Sumatera Utara, menyebutnya dengan istilah dramatis: "antan patah

\footnotetext{
4 Uraian terhadap faktor perkebunan ini sudah banyak dijelaskan antara lain oleh Pelzer, Breman, Stoler, Schadee, dan Veth.
} 
Handep Jurnal Sejarah dan Budaya Vol. 3, No. 1, Desember 2019, hlm. 1-32

lesungpun hilang" (Ikhsan, 2015). Etnik Karo Jehe cenderung menjadi penonton dari semua aktivitas ekonomi perkebunan dan pertambangan yang diboyong ke Eropa.

Sementara itu, sejak tahun 1915 di wilayah gugung dilakukan modernisasi pertanian untuk meningkatkan kesejahteraan masyarakatnya. Batak Instituut yang didirikan tahun 1906 mengutus Sarjana Botje ke Tanah Karo dan mendirikan Balai Penelitian Holtikultura, Bunga, dan Buah-Buahan. Perkenalannya dengan sayur mayur, bunga, dan buah-buahan ini memberikan dampak positif di wilayah gugung, bahkan hingga sekarang ini (Penny, 1964; Singarimbun, 1975; Bangun, 1970). Cara ini dipilih bukan saja untuk memberikan kesejahteraan etnik Karo Gugung, melainkan juga untuk mencegah turunnya orang Karo Gugung ke wilayah jehe, yang dikhawatirkan akan mendorong kolaborasi atau persekongkolan antara orang Karo Gugung dan Karo Jehe melawan Pemerintah Kolonial (Pelzer, 1988).

Langkah terakhir untuk memisahkan etnik Karo adalah dengan cara melakukan reorganisasi pemerintahan tradisionalnya. Walaupun telah dibentuk pejabat-pejabat kolonial, seperti wedana, kontrolir, dan asisten residen yang berasal dari orang Eropa, tetapi Pemerintahan Swapraja (zelfbestuur) tetap diakui. Zelfbestuur ini menjadi kepala-kepala bagi 'kawula raja' (rakyat kerajaan) sekaligus tokoh yang menjembatani kepentingan
Belanda di wilayahnya. Namun, pengakuan terhadap zelfbestuur ini tetap mengindikasikan adanya pembedaan atau pemisahan satuan sosial antara Karo Gugung dan Karo Jehe. Misal, di wilayah gugung disebut sibayak, sedangkan di jehe disebut kesultanan. Keduanya memiliki corak yang sama, antara lain monarki, memiliki badan peradilan (kerapatan) sendiri, memiliki sistem hukum bersendikan adat, memiliki seragam kedinasan, mengenal pengaturan pajak, menerima gaji dan pendapatan.

Meskipun disebut bercorak monarki, tetapi sibayak dan kesultanan lebih mencirikan chiefdom (kepala pemimpin). Raja tidak memiliki kekuasaan mutlak terhadap raja bawahan (datuk). Keadaan ini seperti terjadi di Karo Jehe berkaitan dengan urusan konsesi tanah (Milner, 1982). Selain sebagai bentuk pengakuan terhadap masyarakat lokal, zelfbestuur ini dimaksudkan juga sebagai cara untuk membentuk keterikatan antara inlanders dengan Belanda. Pejabat lokal ini menjadi petugas yang menjembatani rentang kekuasaan, khususnya untuk tugas-tugas yang berkaitan dengan inlanders, sesuai kepentingan kolonialisme. Pada dasarnya, pengakuan terhadap pemerintahan tradisional, yakni sibayak dan kesultanan mengindikasikan adanya pemisahan dan pembedaan. Konsep sibayak di wilayah gugung dianggap berakar dari budaya asli (orisinal) etnik Karo, sedangkan kesultanan di wilayah jehe 
"Gugung dan Jehe: Pembelahan Etnik Karo di Sumatra Utara" (Erond L. Damanik) 1

mengindikasikan nuansa "impor" dan pengaruh Islam.

Keseluruhan upaya pembedaan dan pemisahan ini dilakukan pemerintah kolonial untuk memecah etnik Karo dalam rangka penaklukan (Perret, 2010: 269). Pemisahan ini melahirkan polarisasi nyata pada etnik Karo di wilayah gugung dan jehe. Keduanya dibentuk menjadi daerah administratif yang sesuai karakteristik geografis dan sosiokultural yang tunduk pada pemerintah kolonial (Damanik, 2016: 27). Pada akhirnya, masyarakat pada tiap satuan sosial yang dibentuk ini mengaku berbeda satu sama lain, yakni sebagai Batak Karo dan Melayu.

Namun, unit-unit sosial yang dibentuk, yakni Karo Gugung dan Karo Jehe, memiliki asal usul yang sama. Kedua unit sosial ini mengaku sebagai etnik Karo. Realitas ini dibuktikan dengan kehidupan seharihari dewasa ini yang menunjukkan adanya pemahaman dan penggunaan atribut budaya objektif yang sama seperti aksara Karo, bahasa Karo (cakap Karo), klan (merga silima), busana tradisional, musik, tarian, ornamen, struktur sosial, maupun terms of address (Perret, 2010: 267). Dengan kata lain, masyarakat pada kedua unit sosial ini mengaku sebagai satu kesatuan leluhur (Brahmoputro, 1981: 7; Singarimbun, 1975: 11; Prinst, 1985: 26). Fenomena ini merupakan inti sari pembelahan etnik sebagaimana dijelaskan di awal artikel ini.

\section{Identitas Batak di Gugung dan} Melayu di Jehe

Sebagaimana disebutkan pada uraian di latar belakang, konsep Batak dan Melayu pada kajian ini difokuskan hanya pada etnik Karo. Label "Batak" di sini tidak dimaksudkan untuk menyasar etnik lain yang juga disebut Batak, seperti Simalungun, Mandailing, Pakpak, Angkola, dan Toba. Pada kajian ini, uraian ringkas tentang Batak dimaksudkan guna memahami proses munculnya label "Batak" pada etnik Karo yang bermukim di wilayah gugung, sama halnya dengan proses munculnya label "Melayu" pada etnik Karo yang bermukim di wilayah jehe.

Kedua label ini, yakni "Batak" dan "Melayu", tidak muncul dari dalam etnik Karo tetapi cenderung ditempelkan dari luar, terutama oleh penjelah prakolonialisme, yang kemudian "dipatenkan" pada periode kolonialisme (Perret, 2010). Telaah terhadap sumber Karo prakolonial seperti folklor, karya sastra, dan manuskrip, tidak satupun yang mencantumkan diksi "Batak" ataupun "Melayu". Kenyataan ini sangat kontradiktif bila dihubungkan dengan sumber Barat prakolonial sebagaimana dijelaskan berikut ini.

Referensi paling awal yang menyebut kedua istilah ini berasal dari catatan perjalanan Barat dan Cina (Tuuk, 1861; Junghuhn, 1847; Cortesao, 1944; Viale, 1991; Mills, 1970; Dion, 1970, Groeneveldt, 1960; Reid, 1995). Referensi paling awal bersumber dari Marco Polo di akhir 
Handep Jurnal Sejarah dan Budaya Vol. 3, No. 1, Desember 2019, hlm. 1-32

abad ke-13 yang mencatat Melayu dan Raja Kanibal (Ronald, 1958: 7; Reid, 1995:4). Referensi berikutnya adalah dari de Conti (1430) yang mencatat Batech di Schimuthera (Samudra Pasai), yakni pemukim di pegunungan, gemar berperang, pagan, dan antropopagi (Major 1857). Sumber ini menjadi dasar penyebutan orang Aceh sebagai orang Batak (Gramberg, 1881: 22). Namun setelah mereka menganut agama Islam, kemudian dikategorikan sebagai orang Melayu (Junghuhn, 1847: 27).

Sumber berikut berasal dari Pires tahun 1515 yang mencatat "Bata" sebagai pemukim di antara Aru dan Samudra Pasai (Cortesao, 1944: 87). Besar kemungkinan pemukim ini adalah orang Karo. Kemudian, sumber berikutnya adalah Pinto (1539), yang mencatat "Bata" sebagai pemukim di pantai barat Sumatra, dengan ibu kotanya bernama Panaju (Viale, 1991: 4; Reid, 2009: 16). Selanjutnya, de Barros (1563) mencatat "Batas", yakni pemukim di pulau-pulau yang berhadapan dengan Malaka. Pemukim ini digambarkan gemar berperang dan antropopagi (Dion, 1970: 8). Sumber Cina abad ke-17 menyebut "Bata", yakni pemukim yang posisi tempat hidupnya berada 10 hari perjalanan dari Barus dan digambarkan pagan dan hidup liar (Haan, 1887: 87). Pada 1772, Miller mencatat "Battas", yakni pemukim di pedalaman Tapanuli yang memiliki bahasa, kebiasaan, dan adat khas (Langenberg, 1972: 45; Pleyte, 1895: 2).
Berdasarkan uraian di atas, penyebutan "orang Batak" (Batakvolk) dan "Negeri Batak" (Batakland) cenderung berubah-ubah. Pada awalnya terdapat di Aceh dan bergeser ke Aru (Deli). Selanjutnya bergeser ke pantai barat Sumatra Utara, dan akhirnya menetap di pedalaman Sumatra Utara, yakni di sekitar Danau Toba. Jika mengacu pada peta "Negeri Batak" yang dibuat Junghuhn, wilayahnya memanjang dari pantai barat hingga pedalaman (Junghuhn, 1847: 41). Namun, pada peta itu tidak ditemukan Danau Toba ${ }^{5}$. Kemudian, Joustra memperluas Peta Batakland hingga ke pantai timur mencakup dataran tinggi dan rendah Karo, termasuk Simalungun (Joustra, 1910: 33). Selanjutnya, Collet di tahun 1925 menerbitkan peta bahasa-bahasa di Sumatra Utara yang menempatkan "Negeri Batak" terkonsentrasi di sekitar Danau Toba (Collet, 1925: 34). Peta inilah yang terus diacu hingga kini untuk menyebut "Tanah Batak".

Sejak tahun 1922, kecuali Toba, lima etnik lainnya menolak disebut Batak. Penolakan pertama muncul dalam bentuk pertikaian antara orang Mandailing dan Angkola, terkait kuburan Sei Mati di Medan (Pelly, 2013: 86). Pertikaian ini berdampak antara lain pada segregasi pekerjaan, permukiman, pekuburan, dan sejarah asal-usul. Negasi serupa muncul dari

\footnotetext{
5 Masuknya Danau Toba pada peta dunia (atlas) baru terjadi pascakunjungan van der Tuuk yang menjejakkan kakinya hingga ke pedalaman (Tuuk, 1861: 67).
} 
orang Nias di tahun 1937 (Castels, 2001: 137), orang Karo di tahun 1947, orang Simalungun di tahun 1953 (Dasuha, 2003: 92), serta orang Pakpak di tahun 1971 (Agustono 2010). Bahkan, penolakan merembes hingga ke institusi religius etniknya. Kecuali Toba (HKBP) dan Karo (GBKP), intitusi religius etnik lainnya tidak menempelkan kata "Batak". Misalnya, Simalungun (GKPS), Angkola (GKPPA), ataupun Pakpak (GKPPD) ${ }^{6}$. Perkembangan agama Kristen tidak bisa dilepaskan dari pengaruh kolonialisme. Hal ini berbeda dengan agama Islam yang sudah terlebih dahulu berkembang sejak abad ke-17, yang ditandai dengan penemuan sejumlah nisan di wilayah Jehe, terutama di Klumpang (Moquette, 1922:70), Kota Rentang (McKinnon, 2012), dan Kota Bangun.

Konsep Batak dan Melayu dikenal pada akhir abad ke-13 dan semakin populer sejak awal abad ke-16. Kedua konsep ini berasal dari local informants, yakni para broker perdagangan di wilayah pesisir (Hirousue, 2009:23). Pada akhir abad ke-19, kedua konsep ini dipergunakan pemerintah kolonial

6 Perkembangan institusi religius Kristen Protestan di Sumatra Utara berasal dari dua lembaga zending yang berbeda. Kristen Protestan di Karo dikembangkan oleh NZG Belanda, sedangkan pada kelompok lima etnik lainnya dikembangkan oleh Rheinische Missiongesellschaft (RMG) Jerman. Agama Katolik berkembang sejak tahun 1937 di Samosir, Saribudolog, dan Medan. Agama Methodis berkembang sejak tahun 1935 yang umumnya diterima oleh warga masyarakat di wilayah perkotaan, seperti Medan dan Pematangsiantar. untuk membedakan antara masyarakat yang bermukim di dataran tinggi dengan di dataran rendah. Kedua konsep ini sama sekali tidak merujuk pada particular characteristic etnik, seperti ciri-ciri fenotipe dan genotipe, ras, agama dan religi, makanan dan warna khas, bahasa, aksara, ornamen, musik dan tari, tetapi lebih kepada konstruksi identitas berdasar karakteristik lingkungan geografis dan sosiokultural.

Kedua konsep ini sering mengundang perdebatan sengit terutama berkaitan dengan keanggotaan etniknya. Realitas sosial menunjukkan bahwa orang Karo Jehe yang disebut Melayu adalah etnik Karo yang menganut agama Islam. Sama seperti orang Hataran yang juga disebut Melayu, mereka adalah orang Simalungun yang beragama Islam, maupun orang Pasisir di Tapanuli Tengah (yang adalah orang Toba), Mandailing, Nias, dan Minang yang beragama Islam. Perdebatan ini pada awalnya dipicu oleh penerbitan buku Hutagalung yang menyuguhkan silsilah (tarombo) ke enam halak Batak yang disebut berasal dari Pusuk Buhit (Hutagalung, 1926). Sumber ini terus diacu pada penulisan akademik berikutnya, seperti oleh Vergouwen (1964), dan menjadi referensi yang terus menerus diproduksi hingga kini ${ }^{7}$. Bahkan, sejumlah penulis luar tetap mengacu dan mengukuhkan konsep

\footnotetext{
${ }^{7}$ Lihat: Sangtie, 1977; Siahaan, 1964; Harahap, 1960; Harahap 1987; Rajamarpodang, 1992; Situmorang, 2014; Lumbantobing, 1957.
} 
Batak dan Melayu pada karya mereka ${ }^{8}$. Referensi ini juga menjadi acuan bagi penulis lokal yang meneguhkan habatahon dari berbagai sudut pandang 9 . Tidak hanya penulis Barat, sejumlah penulis lokal pada era kolonialisme tetap mengadopsi dan mengafirmasi konsep Batak pada karya mereka $^{10}$. Kenyataan sama dilakukan pula oleh sejumlah penulis lokal dan Barat pasca-kemerdekaan ${ }^{11}$.

Pola penulisan seperti ini sesungguhnya mengakar dari catatan prakolonial yang membagi masyarakat berdasarkan pandangan sosiogeografis, yakni pedalaman dan pesisir $^{12}$. Catatan-catatan ini menjadi referensi yang tersaji pada $M v O$,

8 Lihat: Cunningham, 1958; Castles, 2001; Hasselgren, 2008; Kipp, 1983; Parkin, 1978; Pedersen, 1975; Schreiner, 2008; Kozok, 2010; Bruner, 1961; Viner, 1980; Keuning, 1954; Adelaar, 1981; Causey, 2006.

9 Lihat: Sinaga, 1981; Aritonang, 1997; Sidjabat, 1981; Nainggolan, 2006; Lumbantobing, 1956; Lumbantobing, 1996.

${ }^{10}$ Lihat: Boemi, 1922; Boerhanoeddin , 1922; Pane, 1922; Soangkupon, 1923.

${ }^{11}$ Karya-karya penulis lokal setara disertasi maupun dalam artikel jurnal senantiasa mematenkan konsep Batak ini. Misalnya, Mandailing-Batak dan Angkola-Batak (Siregar, 1983); Pakpak-Batak (Coleman, 1983); Karo-Batak (Penny, 1964; Singarimbun, 1975; Bangun, 1970); dan Simalungun-Batak (Clauss, 1982; Liddle, 1971; Oudemans, 1973).

${ }^{12}$ Lihat: Joustra, 1910; Meerwadlt, 1922; Schnitger, 1995; Tichelman, 1937; Tidmean, 1936; Westenberg, 1897; Wijngaarden, 1894; Vorhooeve, 1929; Ypes, 1932; Warneck, 1925; Bevervoorde, 1892; Van Dijk, 1894; Masland, 1939; Brenner, 1894; Hagen, 1883; Kroesen, 1886; Couperus, 1852. mededeelingen, bijdragen, notulen, tijdschrift, verhandelingen, verslag, dan surat kabar. Namun, sebenarnya kedua konsep penyeragaman ini telah ditolak Marsden (1774) dan Anderson (1823) karena kegagalan menunjuk masyarakat yang dideskripsikannya. Dalam arti, masyarakat yang dikatakan homogen tersebut pada dasarnya sangat berbeda antara satu dengan lainnya.

Konstruksi identitas Karo Gugung sebagai orang Batak dan Karo Jehe sebagai orang Melayu telah berusia lebih dari 100 tahun. Pelabelan ini telah melintasi tiga era, yakni prakolonial, kolonial, dan kemerdekaan. Pada prakolonial, label ini ditempelkan untuk menyebut kolektivitas masyarakat (bukan suku bangsa) yang bermukim di pegunungan dan pesisir. Pada era kolonial, pelabelan dilakukan secara konstruktif berdasar aspek geografis dan kultural untuk mempolarisasi etnik Karo sebagai bagian dari proses penaklukan. Setelah kemerdekaan, label "Batak" dan "Melayu" masih terus dipergunakan mengacu pada referensi kolonial.

Sesungguhnya pelabelan seperti ini merupakan identitas yang kabur (evasive identity) (Perret, 2010; Damanik, 2018). Kekaburan ini tampak jelas pada kegagalannya menunjuk subjek yang disebut pada kedua label yang dimaksud. Pertanyaan umum yang sering terdengar ialah "Siapakah sesungguhnya Batak dan Melayu itu?" Sejumlah riset mutakhir telah mempertanyakan kedua pelabelan ini (Hirousue, 2009; Pardede, 1979; Reid, 
"Gugung dan Jehe: Pembelahan Etnik Karo di Sumatra Utara" (Erond L. Damanik) 15

2009). Menurut mereka, kedua label ini tidak menunjuk atribut primordial namun lebih kepada atribut sosial yang terbentuk karena perbedaan lingkungan geografis dan sosiokultural. Pada kedua satuan-satuan sosial yang dipisahkan ini ditempelkan karakter atau ciri keberadaban. Keadaban di wilayah jehe, misalnya, lebih ditentukan oleh intensitas pertemuannya dengan pedagang asing sehingga dinyatakan lebih terbuka. Sebaliknya, masyarakat pedalaman seperti Karo Gugung yang hidupnya terisolasi, cenderung menjadi lebih tertutup (Radermacher, 178: 24).

Pembelahan etnik Karo mencerminkan konstruksi identitas selama periode kolonialisme. Pengonstruksian ini selaras dengan pendefinisian kelompok etnik (ethnic group), yakni populasi yang (a) secara biologis mampu berkembang; (b) mempunyai nilai-nilai budaya yang sama dan sadar akan rasa kebersamaannya dalam suatu bentuk budaya; (c) membentuk jaringan komunikasi dan interaksi sendiri; (d) menentukan ciri kelompoknya yang diterima kelompok lain dan dapat dibedakan dari kelompok populasi lain (Naroll, 1964: 12). Pernyataan ini sejalan dengan Castels yang memahami kelompok etnik sebagai komunalistik yang mengacu pada the fundamental source of meaning (Castels, 2001: 11). Identitas ini dipergunakan sebagai upaya legitimizing identity, resistance identity, dan project identity.

Kedua pendapat di atas relevan dengan batasan subjektif etnisitas yang dikemukakan Royce, Hale, Berghe, maupun Glazer seperti telah yang diuraikan di bagian awal. Sebaliknya, pendapat ini bertentangan dengan batasan objektif seperti dijelaskan Geertz dan Shils. Karena itu, pembelahan etnik Karo pada artikel ini cenderung mencerminkan paradigma konstruktif dan menolak paradigma primordial. Ringkasnya, pemisahan etnik Karo menjadi Karo Gugung dan Karo Jehe cenderung dipengaruhi oleh lingkungan geografis, yakni wilayah tempat hidup (dataran tinggi dan rendah) serta kondisi sosiokultural (agama) sebagai alat pembeda. Pembelahan ini menjadi bagian yang tidak terpisahkan dari proses penaklukan selama periode kolonialisme. Sebagai catatan, etnik Karo, Toba, Simalungun, Mandailing, Angkola, Pakpak, Nias, dan Melayu dewasa ini tercatat sebagai "etnik tuan rumah" di Sumatra Utara. ${ }^{13}$ Namun di tahun 2004, "etnik Pasisir", yakni pemukim di pantai barat Tapanuli Tengah, ditetapkan sebagai "etnik tuan rumah" ke- 8 di Sumatra Utara oleh Gubernur Sumatra Utara secara langsung (Hidayat dan Damanik, 2018: 67).

\section{Gugung dan Jehe Adalah Karo!} Sebelum periode kolonialisme, tidak ditemukan adanya fenomena pembelahan etnik Karo. Dengan

\footnotetext{
${ }^{13}$ Etnik Lubu (Loeboes) atau Siladang di pedalaman Mandailing (Kreemer, 1912: 33) tidak tercatat sebagai salah satu kelompok etnik di Sumatra Utara (Damanik, 2018a:87).
} 
kata lain, istilah Karo Gugung dan Karo Jehe baru muncul selama periode kolonialisme. Pernyataan ini mengandung arti bahwa keduanya merupakan etnik yang sama, yakni Karo (Brahmoputro, 1981: 62; Singarimbun 1975: 16). Di awal tulisan telah dijelaskan bahwa pembelahan ini erat kaitannya dengan proses penaklukan yang dilakukan berdasarkan karakteristik lingkungan geografis dan sosiokultural.

Apabila merujuk catatan Anderson tahun 1823, diketahui bahwa pemukim di dataran rendah (Deli, Binjai dan Langkat) adalah etnik Karo. Disebutkan bahwa pemukim di Sunggal, Meidan (Medan), Hamparan Perak, Denai, Kotabangun, Senembah, Bulucina, Tanjungmorawa, Labuhan Brayan, Langkat, Namoukur, Mencirim, dan Binjai adalah etnik Karo yang dicatatnya dengan istilah Carrow atau Karau-karau (Anderson, 1971:101121). Kenyataan lain menunjukkan bahwa pembuka kampung Medan adalah seorang Karo bernama Guru Patimpus Pelawi di tahun 1559 (Perret, 2010). Selain itu, nama kampung di Langkat, Binjai, dan Medan serta Tanjungmorawa identik dengan penamaan Karo (Perret, 2010). Masyarakat dataran rendah (jehe) dan dataran tinggi (gugung) pun memiliki ikatan persaudaran melalui leluhur, perkawinan, dan klan yang sama (Milner, 1982). Aktivitas perdagangan di antara keduanya dihubungkan oleh pedagang yang disebut perlanja sira atau pedagang garam (McKinnon,
1984, 2009; Miksic, 1979).

Kenyataan ini membuktikan bahwa pemukim di dataran rendah adalah etnik Karo yang berdiaspora dari pegunungan. Jalur diaspora ini telah digambarkan Perret melalui perdagangan, berupa munculnya bandar-bandar niaga yang disebut pertumbukan (Perret, 2010). Jadi, jikapun etnik Karo mengalami pembelahan berupa munculnya Gugung dan Jehe, maka pembelahan ini tidak bisa dilepaskan dari faktor kolonialisme (Reid, 2011: xii). Pembelahan ini dilakukan melalui mekanisme sejarah dan sosiokultural serta menjadi bagian dari proses penaklukan.

Di atas telah disinggung bahwa pembelahan mulai dilakukan secara nyata setelah Perlawanan Sunggal (Erman, 2017: 3; Sinar, 1986: 73). Dalam hal ini, periode kolonialisme berperan menciptakan adanya "kesadaran sebagai bagian dari" (Castles 1975: 42; Kipp 1983: 5; Pardede 1979:5). Mekanisme pembelahan dilakukan melalui dua tahap. Pertama, melalui penetapan perbatasan berdasar topografi (pegunungan), sejarah (gagasan tersingkirnya penduduk ke pedalaman), dan politik (daerah yang masih independen). Kedua, melalui pemberian isi kepada masing-masing satuan dengan cara mencari karakteristik yang implisit, yang dipandang sebagai ekspresi kesadaran pemersatu yang mendasar (Perret, 2010). Mekanisme yang pertama memunculkan Karo Gugung dan Karo Jehe, sedangkan mekanisme 
yang kedua memunculkan Batak Karo dan Melayu. Namun keduanya adalah sesama etnik Karo.

Meskipun terdapat upaya penyeragaman etnik Batak dan Melayu, tetapi terdapat sejumlah penulis yang menolaknya ${ }^{14}$. Misalnya, Marsden di tahun 1774 telah menolak penyeragaman ini dengan menyebut adanya etnik bernama Mandiling [Mandailing], Teba [Toba], Ankola [Angkola] dan Pappak [Pakpak] (Marsden, 2008: 7). Etnik ini dikatakan berbeda dari segi bahasa, dialek, kebiasaan, adat istiadat, serta sejarah asal-usulnya. Penolakan yang sama muncul dari Anderson di tahun 1823, yang menyebut adanya etnik Carrow atau Karau-karau [Karo] dan Semilongan atau Semalongan [Simalungun]. Pada catatannya itu, turut disebut etnik lain seperti Mandiling [Mandailing], Pappak [Pakpak], Tubba [Toba], Kapik [Gayo] dan Alas (Anderson, 1971: 43; Damanik, 2017a: 22).

Penyelidikan terhadap manuskrip Karo seperti Pustaka Kembaren dan Pustaka Ginting, tidak mencantumkan adanya Batak Karo maupun Melayu (Neumann, 1902: 33). Bahkan, seluruh tradisi lisan dan pustaka Karo menyebut asal-usul mereka berasal dari sebuah

${ }^{14}$ Penolakan ini telah muncul pada akhir abad ke-18 (Marsden, 2008:7) atau awal abad ke19 (Anderson, 1971:87) maupun di awal Abad 20 (Loeb, 2013:11). Selanjutnya, sejumlah ahli menolak Batak (Pardede, 1975:5; Reid, 2009: 15). Kemudian, dari aspek DNA, orang Karo disebut tidak sezaman dengan orang Toba (Lipson, 2014:xii). daerah yang masuk melalui Pakpak di pantai barat Sumatra. Mereka ini adalah Purba, Barus, Lingga, dan Sitepu yang bermigrasi pada 300-350 SM. Migrasi pertama ini disusul Sembiring pada 150-200 SM. Menurut Neumann, migrasi ini tidak terhenti di dataran tinggi Karo, tetapi terus berlanjut hingga ke lembah Deli dan Serdang (Neumann, 1933: 38). Klan Tarigan menetap di hulu Labuhandeli, sementara klan Lingga menetap di Kuta Lingga, Kerajaan Telu Kuru, Surbakti, dan Gajah di Sunggal.

Klan Kembaren menurut Pustaka Kembaren berasal dari Pagaruyung, Sumatra Barat. Ia adalah seorang anak raja di Pagaruyung yang merantau ke Bangko. Perebutan kekuasaan menyebabkan Kembaren mengungsi ke Alas, lalu berekspansi hingga membentuk Kerajaan Mabar (terletak di antara Medan-Belawan) dan Pertibi di tepi Sei Wampu. Klan Sembiring Meliala tinggal menetap di Siberaya dan berekspansi ke Delitua. Tradisi ini melahirkan Syair Putri Hijau yang sangat populer di kalangan orang Karo, Simalungun, Melayu, Gayo, serta Alas. Dalam syair dikatakan bahwa Putri Hijau memiliki dua saudara laki-laki, yakni Dewa Naga dan Dewa Meriam (Damanik, 2019). Klan Barus dikaitkan dengan Si Mbelang Cuping (Telinga Besar) yang berasal dari daerah Pakpak yang pergi ke Simeme (di selatan Delitua). Ia pergi ke Aceh mencari penghidupan, dan kembali ke Barusjahe. Versi lain menyebut $S i$ Mbelang Pinggol (Telinga Lebar) 
Handep Jurnal Sejarah dan Budaya Vol. 3, No. 1, Desember 2019, hlm. 1-32

berasal dari Barus dan menetap di Senembah. Ia bermigrasi ke Aceh dan mendirikan kampung Senembah sekembalinya dari Aceh (Sinar, 1986: 78). Dua tokoh pada tradisi lisan Karo yakni Si Mbelang Cuping dan Si Mbelang Pinggol adalah tokoh yang sama (Perret, 2010).

Di antara kesusastraan Karo yang diselidiki Neumann, hanya Hikayat Deli yang mencantumkan diksi "Batak"15. Menurut Neumann, klan Karo adalah keturunan Tamil yang masuk dari Barus, berinvasi ke pegunungan lalu menetap di Tanah Karo. Invasi Tamil ini terjadi bersamaan dengan kebangkitan Islam di Barus (Brahmoputro, 1981: 35). Pendapat lain menyebut bahwa tersingkirnya Tamil ke pegunungan adalah dampak invasi Minangkabau pada abad ke-14 (Tidemann, 1936: 4) ${ }^{16}$. Kemudian, Riwayat Hamparan Perak mengisahkan Patimpus Sembiring Pelawi. Ia tinggal di Ajijahe (Batukarang) dan mendirikan kampung di Perbaji. Kemudian, ia pergi ke Langkat untuk menanam lada dan mendirikan kampung bernama Durian

\footnotetext{
15 Kenyataan yang sama terjadi pula pada orang Toba dan Simalungun, yakni tidak ditemukannya kata "Batak" pada kesusastraan dan folklornya (Sangtie, 1977: 23).

${ }^{16}$ Barus adalah situs sejarah tertua di Sumatra Utara. Oleh karena itu, aliran sejarah migrasi yang terjadi di Sumatra Utara umumnya berawal dari Barus. Keberadaan Tamil di Barus, Medan, dan Karo tampak dari temuan artefaktual yang berasal dari India pada abad ke-11 (McKinnon, 1994: 46; Miksic, 1979: 5).
}

Kerajaan, lalu kembali lagi ke Ajijahe. Dari Ajijahe ia turun ke Kotabangun, memeluk agama Islam, dan mendirikan Kampung Meidan (Medan). Guru Patimpus adalah leluhur para datuk di Hamparan Perak (Sepuluhdua Kuta) ${ }^{17}$.

Tahun 1890 misi NZG Belanda menetap di Buluh Awar, Sibolangit, pedalaman Deli. Selanjutnya, di tahun 1902 misi NZG Belanda tersebut menetap di dataran tinggi Karo yakni Kabanjahe. Penyebaran agama Kristen di kalangan orang Karo Gugung erat hubungannya dengan perlawanan Datuk Sunggal. Praktik Pemena, yakni religi asli Karo di wilayah gugung, dianggap pagan dan menjadi pembeda dengan wilayah Jehe yang beragama Islam (Heyne, 1814:7) ${ }^{18}$. Praktik antropopagi pada saat itu disebut masif serta menjadi pembeda antara Karo dengan Melayu (Neumann, 1902:34). Namun, sistem religi di Karo tidaklah tunggal walaupun menunjukkan adanya kemiripan tertentu yang dipandang sebagai varian-varian upacara ritual (Westenberg, 1892:41) ${ }^{19}$.

\footnotetext{
${ }^{17}$ Sutan Ahmad yang bertemu Anderson di tahun 1823 adalah generasi ke-6 dari Guru Patimpus (Anderson, 1971: 48).

${ }^{18}$ Meskipun Warneck (1952:29) menyebut dasar religi dari paganisme berakar dari Hindu, tetapi (Parkin, 1971:4) tetap menganggap agama Toba, yakni Malim, sebagai acuan agama lainnya.

${ }^{19}$ Selain keragaman dalam sistem religinya, di kalangan orang Batak ditemukan pula adanya keragaman pada berbagai aspek lain. Ahli linguistik menemukan adanya perbedaan bahasa pada etnik Batak (Vorhooeve, 1929:55). Bahkan, terdapat perbedaan yang
} 
Pembubuhan kata 'Batak' pada institusi Gereja Karo sering memicu cemoohan: "etnik Karo menolak Batak, tetapi pada institusi religiusnya terdapat kata Batak". Sesungguhnya, munculnya frasa "Batak" pada institusi religiusnya tidak bisa dilepaskan dari peristiwa pasca-Revolusi Sosial (1946) yang memicu permusuhan antara pemuda Karo, Gayo-Alas dan Toba di Tigalingga $^{20}$. Kerusuhan ini mendorong munculnya kesepakatan antara orang Karo dengan Toba yang dimediasi oleh militer di Kabanjahe (Panjaitan, 1974: 5). Salah satu kesepakatannya ialah membubuh-kan kata "Batak" pada institusi religiusnya. Pembubuhan ini dimaksudkan sebagai cara menciptakan kekerabatan, kedekatan, persaudaraan, dan perdamaian (Castles 2001: 14; Langenberg, 1977: 23).

Struktur sosial orang Karo didasarkan pada kekerabatan patrilineal (patrilineal descent). Setiap individu mengategorikan dirinya berdasar garis keturunan (agnates), seperti pemberi istri (wife-givers) dan penerima istri (wife-receivers). Etnik Karo lebih menekankan aspek genealogi pada leluhur, yakni dominance-subordination dari pemberi

mencolok pada bahasa ataupun logat (dialek) yang terdapat di dalamnya (Viner, 1980:3). Perbedaan terlihat pula pada tampilan fisik, pakaian, adat, serta karakter etnonasionalismenya (Haan, 1887: 7).

${ }^{20}$ Pada saat itu terjadi pembunuhan, pembakaran dan pengusiran etnik Toba dari wilayah Pakpak di wilayah Karo Kampung, yakni di Tigalingga dan Tanah Pinem (Langenberg, 1977: 44). dan penerima istri. Selain itu, etnik Karo hanya mengetahui leluhurnya hingga 3 atau 4 generasi sebelumnya ${ }^{21}$. Gambaran ini menunjukkan adanya perbedaan sikap di antara kelompok Batak (Joustra, 1910: 18) maupun perbedaan dalam sistem organisasi tradisionalnya. Menurutnya, tidak satupun etnik Batak yang telah memiliki organisasi politik yang mantap sebelum pendudukan Belanda (Castles, 1975: 27). Selain itu, leluhur sultan-sultan Melayu adalah orang Karo yang beralih menjadi Islam (Perret, 2010: 416). Kenyataan ini dibuktikan oleh sastra lisan, pustaka, maupun penamaan di hampir seluruh wilayah yang memiliki kedekatan dengan kosakata Karo. Selain itu, pada upacara-upacara adat, kehadiran sultan-sultan Melayu di pedalaman menunjukkan adanya kesamaan sejarah asal-usulnya. Jadi, Karo di pegunungan dan pesisir sesungguhnya memiliki leluhur yang sama.

Literatur Antropologi Indonesia, telah mencatat bahwa Toba, Simalungun, Karo, Pakpak, Mandailing dan Angkola adalah etnik Batak. Muncul dan populernya ke-6 etnik

\footnotetext{
${ }^{21}$ Etnik Toba cenderung menekankan genealogi dan orientasinya kepada leluhur. Etnik Pakpak lebih mengedepankan geografisnya yang disebut dengan suak, yakni wilayah subkultur etnik Pakpak yang terdiri dari lima suak dengan mengabaikan asal usul leluhur atau nenek moyang. Sementara itu, etnik Simalungun cenderung lebih menekankan kepada wilayah geografis marga (clan territorial) daripada leluhur atau nenek moyangnya.
} 
Handep Jurnal Sejarah dan Budaya Vol. 3, No. 1, Desember 2019, hlm. 1-32

yang disebut "Suku Batak" tidak terlepas dari tulisan Payung Bangun yang berjudul "Kebudayaan Batak" (Bangun, 1970: 22). Tulisan ini disunting Koentjaraningrat dalam buku bunga rampainya yang bertajuk "Masyarakat dan Kebudayaan Indonesia" (Koentjaraningrat 1982). Literatur ini menjadi referensi yang paling sering dirujuk di Indonesia, yang menyebut Karo sebagai "etnik Batak". Berdasarkan uraian ini, pemukim yang berada di wilayah gugung dan jehe merupakan etnik yang sama, yakni Karo.

\section{Pembelahan Etnik: Fenomena Konstruksi Identitas}

Pemisahan dan pembelahan etnik Karo muncul karena dua faktor yakni perbedaan geografi dan sosiokultural. Faktor pertama, membagi wilayah Karo menjadi dataran tinggi (hinterland) dan dataran rendah (lowland). Karo Gugung atau Karo plateau adalah bagian pegunungan Bukit Barisan, sedang jehe adalah dataran rendah Deli (Deli lowland). Berdasar pada tipologi geografi ini, Karo Gugung disebut masyarakat pedalaman (inland societies) yang mencerminkan keterasingan dari dunia luar, sedang Karo Jehe disebut masyarakat pesisir (coastal societies) yang mencerminkan keterbukaan terhadap dunia luar. Selanjutnya, faktor kedua yaitu sosiokultural membagi etnik Karo menjadi Batak Karo dan Melayu. Dalam hal ini, agama menjadi basis pembeda yang tajam. Agama dianggap menjadi kesadaran dan identitas pemersatu. Di wilayah gugung yang masyarakatnya menganut Pemena, yakni kepercayaan asli orang Karo, dianggap pagan. Di wilayah jehe masyarakatnya telah menganut agama Islam. Selanjutnya, pada kedua satuan sosial yang dibelah ini diberikan isi beraroma politis yang tampak pada istilah pemerintahan tradisional, yakni sibayak di gugung dan kesultanan di jehe. Aroma ekonomi turut ditempelkan yakni hortikultura di gugung dan perkebunan di jehe.

Pembelahan etnik Karo seperti ini sama sekali tidak menunjuk pada fenomena pembelahan atribut primordial, namun lebih kepada fenomena konstruktif, yaitu pemisahan yang dimungkinkan oleh perbedaan lingkungan geografis dan sosiokultural. Asumsi ini didukung oleh realitas sosial bahwasanya kedua satuan yang dibedakan ini memiliki dimensi etnisitas objektif yang sama, yakni bahasa, klan (clan), busana tradisional, salam khas tradisi, sejarah asal usul, struktur dan sistem sosial. Hanya saja, faktor kolonialisme membuat kedua satuan ini memiliki perbedaan yang kontras. Walaupun demikian, faktor geografi dan sosiokultural ini tidak menimbul-kan deep-rooted ethnic boundary (Gordon, 1964: 23; Naroll, 1964: 283; Barth, 1969: 12, Regina, 2011: 241). Realitas sosial seperti ini tampak pada beberapa hal, seperti adanya atribut objektif yang sama pada kedua satuan sosial yang terpisahkan. Pernyataan ini merupakan asumsi 
"Gugung dan Jehe: Pembelahan Etnik Karo di Sumatra Utara" (Erond L. Damanik) 21

teoretis terdahulu, yang kemudian diuji dan menghasilkan novelty kajian ini, bahwa pembelahan etnik adalah fenomena konstruksi identitas.

Identitas etnik dapat dilihat secara objektif, yakni ciri-ciri yang tampak seperti genetik, fenotipe, linguistik, religiositas, dan kultural (Royce, 1982: 18), maupun secara subjektif yang menunjuk pada pengakuan (self referential). Berdasarkan ketentuan ini, temuan kajian menunjukkan bahwa selama periode kolonialisme, fenomena pengonstruksian identitas etnik lebih bersifat subjektif. Meskipun kolonialisme dipandang menciptakan "kesadaran sebagai bagian dari", tetapi penciptaan kesadaran ini tetap dilakukan dalam koridor proses penaklukan. Pernyataan ini menguatkan asumsi teoretis terdahulu bahwa fenomena konstruksi identitas merupakan gejala manipulatif, dinamis dan cair. Pandangan ini relevan dengan pernyataan Glazer bahwa etnisitas adalah "kelompok kepentingan", ataupun menurut Hale merupakan "alat" untuk meraih sumber daya material, ekonomi, sosial dan politik. Konstruksi identitas merupakan "permainan etnik" sesuai "kemantapan strategis" etniknya. Pada konteks ini, selama periode kolonialisme masingmasing satuan sosial yang dipisahkan sama-sama memiliki peluang sosial, tetapi hanya dapat dicapai apabila berkolaborasi dengan pemerintah kolonial.

Pada akhirnya, pembelahan etnik pada satuan-satuan sosial yang lebih kecil ini berfungsi untuk memudahkan pengawasan dan pengendalian masyarakat. Uraian yang telah disajikan sebelumnya dapat memberikan pemahaman tentang mekanisme pembelahan etnik Karo yang nyata terjadi pada era kolonial, dengan mengacu pada benteng alam dan benteng budaya. Pembelahan ini menjadi lebih mungkin dilakukan mengingat keterkaitan situasi etnisitas pada peluang-peluang sosial, ekonomi, dan politik yang ditawarkan pemerintah kolonial. Berdasarkan uraian di atas, temuan penelitian mengukuhkan bahwa pembelahan etnik Karo merupakan fenomena pengontruksian identitas etnik pada periode kolonialisme. Pengontruksian mengacu pada basis sosio-geografis dan sosiokultural yang keduanya ditekankan melalui politik, ekonomi, dan sosial selama proses penaklukan.

\section{SIMPULAN}

Pembelahan etnik Karo dalam dua kelompok, yakni Karo Gugung dan Karo Jehe, merupakan langkah nyata pengontruksian identitas etnik yang terjadi selama periode kolonialisme. Dikotomi Gugung dan Jehe dilakukan berdasarkan perbedaan acuan sosiogeografis dan sosiokultural. Mekanisme pembelahannya dilakukan melalui 4 langkah, yaitu (i) pengerdilan wilayah etnik, (ii) pemberian isi pada satuansatuan sosial yang dibentuk, (iii) pembedaan berdasarkan atribut sosial yang nyata, dan (iv) pengakuan terhadap satuan-satuan sosial yang telah 
dibentuk.

Pembelahan etnik tersebut sama sekali tidak mengacu pada atribut primordial yang given dan alamiah, tetapi lebih kepada pembentukan identitas baru mengikuti proses budaya dan sejarah, yang mengarah pada penaklukan. Proses sejarah dan budaya ini mendapat suntikan pengaruh politik, ekonomi, dan sosial yang menekankan adanya perbedaan pada satuan-satuan sosial yang dibentuk. Meskipun kolonialisme berperan meneguhkan "kesadaran sebagai bagian dari", tetapi pemisahan ini tidak serta merta menghasilkan deep-rooted ethnic boundary, karena kedua satuan sosial yang dibentuk masih memiliki keterikatan melalui bahasa, klan, sistem dan struktur sosial, serta sejarah asalusul yang sama.

Kajian ini menekankan bahwa etnisitas adalah fenomena manipulatif, dinamis, dan cair. Etnisitas dipandang sebagai kelompok kepentingan yang menunjuk pada permainan etnik sesuai kemantapan strategis yang mengelilinginya. Etnisitas adalah alat untuk meraih peluang-peluang sosial.

\section{DAFTAR SUMBER}

Adelaar, A.K. 1981. Reconstruction of Proto-Batak Phonology. Nusa 10, hlm. 1-20.

Agustono, B. 2010. Rekonstruksi Identitas Etnik: Sejarah SosialPolitik Orang Pakpak di Sumatera Utara (1958-2003). Disertasi. Yogyakarta: Program Pascasarjana
Fakultas Ilmu Budaya, Universitas Gadjah Mada.

Agustono, B., Tanjung, M.O., \& Suhartono, E. 1997. Badan Perjuangan Rakyat Penunggu Indonesia vs PTPN II. Medan: AKATIGA.

Anderson, J.1971. Mission to the Eastcoast of Sumatra in 1823. Kuala Lumpur: Oxford in Asia Historical Reprints.

Aritonang, J. 1997. Sejarah Pendidikan Kristen di Tanah Batak. Jakarta: BPK Gunung Mulia.

Bangun, P. 1970. "Kebudayaan Batak," dalam Koentjaraningrat (ed.), Masyarakat dan Kebudayaan Indonesia. Jakarta: Grafiti Press, hlm. 47-64.

Barth, F. 1969. Ethnic Groups and Boundaries: The Social Organization of Culture Difference. London: Allen and Unwin.

Berghe, P.L. van den. 1981. The Ethnic Phenomenon. New York: Elsevier.

Bevervoorde, K. Th. E. van. 1892. Een Bezoek Aan de Bataksche Hoogvlakte. 12 Februari.

Boemi, A.E.1922. Het Grondenrecht in de Bataklanden: Tapian Naoeli, Simeloengen en het Karoland. Leiden: Eduard Ydo.

B o e rhanoed din. $\quad 1922$. Huwelijkgebruiken in Mandailing (Tapanoeli). Koloniale Studien II, hlm. 302-310. 
"Gugung dan Jehe: Pembelahan Etnik Karo di Sumatra Utara" (Erond L. Damanik) 23

Brahmoputro. 1981. Karo dari Jaman ke Jaman. Medan: Yayasan Masa.

Breman, J. 1997. Menjinakkan Sang Kuli: Politik Kolonial pada awal Abad Ke-20. Jakarta: Grafiti.

Brenner, J.F. 1894. Besuch bei den Kanibalen Sumatras: Erste Durchquerung der Unabhangigen Batak-Lande. Wurzburg: Woerl.

Bruner, E.M. 1961. Urbanization and Ethnic Identity in North Sumatra. American Anthropologist LXIII, hlm. 508-521.

—_- 1981. "Migration and Segmented Self," dalam Rainer Carle (ed.), Cultures and Societies of North Sumatera. Hamburg: Dietrich Reimer Verlag, hlm.133149.

1992. "Kerabat dan Bukan Kerabat," dalam T.O. Ichromi (ed.), Pokok-Pokok Antropologi Budaya. Jakarta: Obor Indonesia, hlm. 5769.

Castles, L. 1975. "Statelessness and State Forming Tendencies among the Batak before Colonial Rule," dalam Anthony Reid and Lance Castels (ed.), Pre-Colonial State System of Southeast Asia. Kuala Lumpur: Malaysian Branch of the Royal Asiatic Society. Monograph No. 6, hlm. 67-76.

2001. Kehidupan Politik Suatu Karasidenan di Sumatera: Tapanuli 1915-1940. Jakarta: Gramedia Pustaka Utama.
Causey, A. 2006. Danau Toba: Pertemuan Wisatawan dengan Batak Toba di Pasar Suvenir. Medan: Bina Media Perintis.

Clauss, W. 1982. Economic and Social Change Among the Simalungun Batak of North Sumatra. Saarbrucken: Verlag Breitenbach Publishers.

Coleman, R.G. 1983. Pakpak Batak Kins Group and Land Tenure: A Study of Descent Organization and its Cultural Ecology. Columbia: Columbia University Press.

Collet, O.J.A. 1925. Terres et Peuples de Sumatra. Amsterdam: Elsevier.

Cortesao, A. 1944. The Suma Oriental of Tome Pires. London: Hakluyt Society.

Couperus, P.Th. 1852. De Residentie Tapanoeli van Sumatra Weskust in 1852. Tijdschrift voor Indische Taal-, Land -en Volkenkunde 4, hlm. 216-256.

Cunningham, C.E. 1958. The Postwar Migration of the Toba Bataks to East Sumatra. Yale: Yale University Southeasth Asia Studies.

Damanik, E.L 2016. Kisah dari Deli: Historisitas, Pluralitas dan Modernitas Kota Medan Tahun 1870-1942. Medan: Simetri Institute.

-. 2017a. Rumor Kanibal, Menolak Batak dan Jejak Perdagangan: Etnohistori Sumatra Bagian Utara. Medan: Simetri Institute. 
Handep Jurnal Sejarah dan Budaya Vol. 3, No. 1, Desember 2019, hlm. 1-32

___. 2017b. "Sumatra dan

Kabar-Kabar Kanibalisme," dalam Sri Sugiharta (ed.), Sumatra Silang Budaya: Kontestasi Nilai-Nilai Historis, Arkeologis, dan Antropologis serta Upaya Pelestarian Cagar Budaya. Batu Sangkar: BP3 Batusangkar, hlm 17-33.

2018. Menolak Evasive Identity: Memahami Dinamika Kelompok Etnik di Sumatra Utara. Anthropos: Jurnal Antropologi Sosial dan Budaya, Vol. 4, No. 1, hlm. 9-22.

Dasuha, J.R.P. 2003. Tole den Timorlanden das Evanggelium: Sejarah Seratus Tahun Injil di Simalungun, 1903-2003. Pematang Siantar: Bina Media Perintis dan Kolportase GKPS.

Dewi, T.K. 2004. Poenale Sanctie: Studi tentang Globalisasi Ekonomi dan Perubahan Hukum di Sumatra Timur, 1870-1950. Medan: USU Press.

Dijk, P.A.L.E van. 1894. Rapport betreffende de Si Baloengoensche Landschappen Tandjung Kasau, Tanah Jawa, en Si Antar. Tijdschrift voor Indische Taal, Land-en Volkenkunde 37, hlm. 145-200.

Dion, M. 1970. Sumatra through Portuguese Eyes: Excerpts from Joao de Barros. Indonesia 9, hlm. 129-162.

Erman, E. 2017. Chinese Taukeh, Labourer, and State Control: Case
Study of Panglong in Eastern Region of Sumatra (1890-1930). Wacana, Vol. 18, No. 2, hlm. 514 39.

Francis, E.K. 1976. Interethnic Relations: An Essay in Sociological Theory. New York: Elsevier.

Galloway, P. 2006. Practicing Ethnohistory: Mining Archives, Hearing Testimony, Constructing Narratives. Lincoln: University of Nebraska Press.

Geertz, C. 1963. "The Integrative Revolution: Primordial Sentiments and Civil Politics in the New States," dalam C. Geertz (ed.), Old Societies and New States. New York: Free Press, hlm.105-157.

1975. "The Expression of Ethnicity in Indonesia," dalam Abner Cohen (ed.), Urban Ethnicity: ASA Monograph 12. London: Tavistock, hlm. 275-289. 1982. "Introduction," dalam Karl J. Pelzer (ed.), Planters, against Peasant: The Agrarian Struggle in East Sumatra, 19471958. Gravenhage: Nijhof, hlm. viixii.

Glazer, N. 1963. Beyond the Melting Pot: The Negroes, Puerto Ricans, Jews, Italians, and Irish of New York. Massachusetts: The MIT Press.

Gramberg, J.S.G. 1881. de Ooskust van Sumatra. Indische Gids III, hlm. 587-593. 
"Gugung dan Jehe: Pembelahan Etnik Karo di Sumatra Utara" (Erond L. Damanik) 25

Groeneveld, W.P. 1960. Historical Notes on Indonesia and Malaya: Compiled from Chinese Source. Jakarta: Bharata.

Gordon, M.M. 1964. Assimilation in American Life: The Role of Race, Religion and National Origins. Oxford: Oxford University Press.

Haan, F. de. 1887. Een oud Bericht Aangaande de Batta's. Tijdschrift voor Indische Taal-, Land -en Volkenkunde 39, hlm 647-48.

Hagen, D.B. 1883. Zu den Wanderungen der Battas. Das Ausland 01, hlm. 9-13.

Hale, H.E. 2004. Explaining Ethnicity. Comparative Political Studies 37 (4), hlm. 458-485.

. 2008. The Foundations of Ethnic Politics: Separatism of States and Nations in Eurasia and the World. Cambridge, UK: Cambridge University Press.

Harahap, B.H. 1987. Orientasi NilaiNilai Budaya Batak: Suatu Pendekatan terhadap Perilaku Batak Toba dan AngkolaMandailing. Jakarta: Sanggar Willem Iskandar.

Harahap, E.S. 1960. Perihal Bangso Batak. Jakarta: Djawatan Kebudayaan Departemen Pendidikan.

Hasselgren, J. 2008. Batak Toba di Medan: Perkembangan Identitas Etno-Religius Batak Toba di Medan, 1912-1965. Medan: Bina
Media Perintis.

Heyne, B. 1814. Tracts, Historical and Statistical on India: an Account of Sumatra. Oxford: Printed for the Radcliffe Trustees.

Hidayat dan E.L. Damanik. 2018. Batak dan Bukan Batak: Paradigma Sosiohistoris Tentang Konstruksi Identitas Etnik di Kota Medan, 1906-1939. Jurnal Sejarah Citra Lekha, Vol. 3, No. 2, hlm. 71-87.

Hirousue, M. 2009. "The Role of Local Informants in the Making of the Image of Cannibalism in North Sumatra," dalam Dominik Bonatz et al (ed.), From Distant Tale: Archaelogy and Ethnohistory in the Highlands of Sumatra. Newcastell: Cambridge Scholars Publishing, hlm.169-194.

Hutagalung, W.M. 1926. Poestaha Taringot Toe Tarombo Ni Bangso Batak. Laguboti: Zendingsdrukkerij.

Holloman, E.H dan S.A. Arutiunov. 2011. Perspectives on Ethnicity (World Anthropology). Berlin, Germany: De Gruyter Mouton.

Ikhsan, E. 2015. Konflik Tanah Ulayat dan Pluralisme Hukum: Hilangnya Ruang Hidup Orang Melayu Deli. Jakarta: Pustaka Obor Indonesia.

Joustra, M. 1910. Batakspiegel: Uitgave van Het Bataksch Instituut No. 3. Leiden: S.C. van Doesburgh. Junghuhn, F. 1847. die Battalander auf Sumatra. Berlin: G. Reimer. 
Handep Jurnal Sejarah dan Budaya Vol. 3, No. 1, Desember 2019, hlm. 1-32

Keuning, J. 1954. Toba-Bataks en Mandailing-Bataks. Indonesia 7, hlm. 170-71.

Kipp, R.S. 1983. Beyond Samosir: Recent Studies of the Batak Peoples of Sumatera. Ohio: Ohio University Center for International Studies, Southeast Asia Program.

Koentjaraningrat. 1982. Masyarakat dan Kebudayaan Indonesia. Jakarta: Grafiti Press.

Kozok, U. 2010. Utusan Damai di Kemelut Perang: Peran Zending dalam Perang Toba. Jakarta: Yayasan Pustaka Obor Indonesia, École française d'Extrême- Orient, Pusat Studi Sejarah dan Ilmu-ilmu Sosial Unimed, Sekolah Tinggi Teologi Jakarta.

Kreemer, J. 1912. de Loeboes in Mandailing. Bijdragen tot de Taal,Land-,en Volkenkunde van Netherland Indie, 66, hlm. 304335.

Kroesen, J.A. 1886. Nota Omtrect de Bataklanden. Tijdschrift voor Indische Taal-, Land -en Volkenkunde XLI, hlm. 253-285.

Langenberg, M.V. 1972. Charles Miller's Accounts of Sumatra. Review of Indonesian and Malayan Affairs, Vol. 6, No. 1, hlm. 116-130. 1977. National Revolution in North Sumatra: Sumatra Timur and Tapanuli, 1942-1950. Disertasi. Sidney: University of Sidney.
Liddle, R.W. 1971. Ethnicity, Party and National Integration: An Indonesian Case Study. New Heaven and London: Yale University Press.

Lipson, M. 2014. New Statistical Genetic Methods for Elucidating the History and Evolution of Human Populations. Tesis. Massachusetts: Department of Mathematic, Massachusetts Institute of Technology.

Loeb, E.M. 2013. Sumatra: Sejarah dan Masyarakatnya. Yogyakarta: Ombak.

Lumbantobing, A. 1957. Sedjarah Si Singamangaradja I-XII. Medan: Firma Sihombing. . 1996. Makna Wibawa Jabatan dalam Gereja Batak. Jakarta: BPK Gunung Mulia.

Lumbantobing, P. 1956. The Structure of the Toba Batak Belief in High God. Amsterdam: Jacob van Campen.

Major, R.H. 1857. "The Travels of Nicolo Conti in the East (in the Early part of the 15th Century," dalam R.H. Major (ed.), India and the Fifteenth Century. New York: Burt Franklin, hlm. 4-19.

Marsden, W. 2008. Sejarah Sumatra. Jakarta: Komunitas Bambu.

Masland, J.H. 1939. de Bloedgroepen der Mandailingers. Geneeskundige Tijdschrift voor Nederlands Indie, LXXIX, hlm. 392-401. 
"Gugung dan Jehe: Pembelahan Etnik Karo di Sumatra Utara" (Erond L. Damanik) 27

McKinnon, E.E. 1994. Tamil Imagery in Northeast Sumatra. Oriental Art, Vol. XL, No. 3, hlm. 16-23.

McKinnon, E.E. et al. 2009. "Ceramics, Cloth, Iron and Salt: CoastalHinterland Interaction in the Karo Region of Northeastern Sumatra," dalam D. Bonatz, J. Miksic, J.D. Neidel, M.L.Tjoa-Bonatz (ed.), From Distant Tales: Archaeology and Ethnohistory in the Highlands of Sumatra. Newcastle: Cambridge Scholars Publishing, hlm. 120-142. 2012. "The Kota Rentang Excavations," dalam Dominik Bonatz, Andreas Reinecke and Mai Lin Tjoa-Bonatz (ed.), Connecting Empires: $\quad$ Selected Papers from the 13th International Conference of the European Association of the Southeast Asian Archaeologist, Volume-2. Singapore: NUS Press, hlm. 66-80.

Meerwadlt, J.H. 1922. Die Nieuwe Bataksche Letterkunde. Tijdschrift voor Zendelinwetenschap: Mededelingen 66, hlm. 513-550.

Miksic, J.N. 1979. Archaeology, Trade and Society in Northeast Sumatra. Tesis. New York: Faculty of the Graduate School of Cornell University Ithaca.

Mills, J.V.G. 1970. Ma Huan: Ying-Yai Sheng-lan. The Overall Survey of the Oceans Shore. Cambridge, UK: Cambridge University Press.

Milner, A.C. 1982. Kerajaan: Malay Political Culture on the Eve of Colonial Rule. Tucson: The University of Arizona Press.

Moquette, J.P. 1922. de Graafsteen van Kloempang (Deli). Oudheikundig Verslag II-III, hlm. 70-71.

Nainggolan, T. 2006. Batak Toba di Jakarta: Kontinuitas dan Perubahan Identitas. Medan: Bina Media Perintis.

Naroll, R. 1964. On Ethnic Classification. Current Anthropology, Vol 5, No. 4, hlm. 283-312.

Neumann, J.H. 1902. Deli-Zending. Verslag Aangaande den Toestand der Zendingswerkzaamheden en der Gemeente in het Ressort Sibolangit over het Jaar 1901. Mededeelingen van Wege Het $N e d \quad e \quad r \quad l \quad a \quad n d s \quad c h$ Zendelinggenootschap 46, hlm.6374

- 1933 . Bijdrage tot de Geschiedenis der KaroBatakstammen. Bijdragen tot de Taal- en Volkenkunde van de Koninklijk Instituut, 1933, hlm. 136.

Oudemans, R. 1973. Simalungun Agriculture: some Ethnographic Aspects of Dualism in North Sumatra Development. Tesis. Maryland: Department of Agriculture College Park, University of Maryland.

Pane, S.P. 1922. Adat Batak. Pematangsiantar: Soetan Pane.

Panjaitan, J. Th. 1974. Panggilan dan Suruhan Allah, 75 Tahun 
Pekabaran Injil HKBP, 1879-1974.

Pematangsiantar: STT HKBP.

Pardede, J. 1979. die Batakchristen auf Nord Sumatra und ihr Verhaltnis zu den Muslimen. Disertasi. Mainz: Johannes Gutenberg Universitat.

Parkin, H. 1978. Batak Fruit, Hindu Thought. Madras: The Doecesan Press.

Pangdam II/BB, T.A. 1977. Sejarah Perjuangan Komando Daerah Militer II Bukit Barisan. Medan: Dinas Sejarah Kodam II Bukit Barisan.

Pedersen, P.B. 1975. Darah Batak, Jiwa Protestan: Perkembangan GerejaGereja Batak di Sumatra Utara. Jakarta: BPK Gunung Mulia.

Pelly, U. 2013. Urbanisasi dan Adaptasi: Peranan Misi Budaya Minangkabau dan Mandailing di Kota Medan. Medan: Unimed Press \& Casa Mesra.

Pelzer, K.J. 1988. Toean Keboen dan Petani: Politik Kolonial dan Perjuangan Agraria di Sumatra Timur, 1863-1847. Jakarta: Pustaka Sinar Harapan.

Pemdasu. 1994. Sejarah Perkembangan Pemerintahan Propinsi Daerah Tingkat I Sumatera Utara. Medan: Pemdasu dan Diklat Propsu.

Penny, D.H. 1964. the Transition from Subsistence to Commercial Family Farming in North Sumatra. Tesis. New York: Department of Agricul- ture. Ithaca, Cornell University.

Perret, D. 2009. "Ethnicity and Colonization in Northeast Sumatra: Bataks and Malays," dalam J. N. Miksic (ed.), From Distant Tales: Archaeology and Ethnohistory in the Highlands of Sumatra. New Castells: Cambridge Scholars Publishing, hlm.57-69.

. 2010. Kolonialisme dan Etnisitas: Batak dan Melayu di Sumatra Timurlaut. Jakarta: KPG dan EFEO Prancis.

Pleyte, C.M. 1895. De Verkenning Der Bataklanden. Tijdschriff van de Nederlandsch Aardrijkundig Genootschap XII, hlm. 72-73.

Prinst, D.. 1985. Sejarah dan Kebudayaan Karo. Kabanjahe: Yrama.

Prima, B.S. 1976. Perjuangan Kemerdekaan dalam Wilayah Sumatera Utara: Medan Area Mengisi Proklamasi. Medan: Badan Musyawarah Perjuangan Republik Indonesia Medan Area.

Radermacher, J.C.M. 1781. Beschrijving van het eiland Sumatra. Verhandelingen van de Bataviasch Genootschap 3, hlm.189.

Rajamarpodang, Dj.G. 1992. Dalihan Na Tolu: Nilai Budaya Suku Batak. Medan: Media Sarana.

Ramadhan, KH. 2008. Ibnu Sutowo: Saatnya Saya Bercerita. Jakarta: National Press Club of Indonesia 
"Gugung dan Jehe: Pembelahan Etnik Karo di Sumatra Utara" (Erond L. Damanik) 29

Reid, A. 1992. Perjuangan Rakyat:

Revolusi dan Hancurnya Kerajaan Tradisional di Sumatra. Jakarta: Sinar Harapan.

- 1995. Witnesess to Sumatra: A Travellers Anthology. Kuala Lumpur: Oxford University Press in Asia.

2009. "Is there Batak History?," dalam J.N. Miksic (ed.), From Distant Tales: Archaeology and Ethnohistory in the Highlands of Sumatra. New Castells: Cambridge Scholars Publishing, hlm. 104-119.

——_. 2011. Menuju Sejarah Sumatra: Antara Indonesia dan Dunia. Jakarta: KITLV dan Obor Indonesia.

Rogers, J.D. 1993. Ethnohistory and Archaeology: Approaches to postcontact change in the Americas. New York and London: Plenum Press.

Ronald, L. 1958. Cannibals and Kings: Northern Sumatera in the 1290s. the Travels of Marco Polo. Harmondsworth: Penguins Books.

Royce, A.P. 1983. Ethnic Identity: Strategies of Diversities. Bloomingston: Indiana University Press.

Sangtie, B. 1977. Sejarah Batak. Balige. Karl Sianipar Company.

Said, M. 1977. Koeli Kontrak Tempo Doeloe dengan Derita dan Kemarahannya. Medan: Waspada.
Schadee, W.H.M. 1919. Geschiedenis van Sumatra's Ooskust. Amsterdam: van Mantgem.

Schnitger, J.M. 1995. "Ruins of an Unknwon Kingdom," dalam Anthony Reid (ed.). Witnesess to Sumatra: A Travellers Anthology. Kuala Lumpur: Oxford in Asia Historical Reprints, hlm. 327-329.

Schreiner, L. 2008. Adat dan Injil: Perjumpaan Adat dengan Iman Kristen di Tanah Batak. Jakarta: BPK Gunung Mulia.

Siahaan, N. 1964. Sedjarah Kebudayaan Batak: Suatu Studi Tentang Suku Batak. Medan: Napitupulu \& Sons.

Sidjabat, W.B. 1981. Ahu Si Singamangaraja. Jakarta: Sinar Harapan.

Sinaga, A.B. 1975. the Toba Batak High God: Transendence and Immanence. St. Augustin: Anthropos Institute.

Sinar., T. L. 1986. Sari Sedjarah Serdang (Jilid I). Jakarta: Departemen Pendidikan dan Kebudayaan. 1988. Perang Sunggal (18721895). Medan: Dinas Pendidikan dan Kebudayaan Kota Medan.

Singarimbun, Masri. 1975. Kinship, Descent and Alliance among the Karo Batak. Los Angeles: University of Carolina Press.

Siregar, Diapari. 1922. de Bataksche Taal. Jong Sumatra 6. hlm 4-7. 
Siregar, Susan Rodger. 1983. "Political Oratory in a Modernizing Southern Batak Homeland," dalam Rita Smith Kipp (ed.), Beyond Samosir: Recent Studies of the Batak Peoples of Sumatra. Ohio: Ohio University Center for International Studies, Southeast Asia Program, hlm.118127.

Situmorang, S. 2014. Toba na Sae: Sejarah Lembaga Sosial Politik Abad XIII-XX. Jakarta: Komunitas Bambu.

Soangkupon, M. 1923. Bataksche Adat. Koloniale Studien II, hlm.75-101.

Shills, E.1957. Primordial, personal, sacred and civil ties. British Journal of Sociology, Vol. 8, No. 2, hlm. 130-145.

Stoler, A.L. 1985. Capitalism and Confrontation in Sumatra's Plantation belt, 1870-1979. New Haven: Yale University Press.

Strong, P.T. 2015. "Ethnohistory," dalam J. D. Wright (ed.), International Encyclopedia of the Social and Behavioral Sciences Vol. 8, 2nd ed. New York: Elsevier, hlm. 192-197.

Tichelman, G.L. 1937. Mededelingen beschrijins van heiden-Bataksch begrafenish in Simeloengen (Sumatra Ooskust). Tijdscrift Voor Indische Taal, Land en Volkenkunde Batavia LXXIV, hlm. 506-511.

Tambak, Bandar Alam Purba dan Herman Purba Tambak. 2019.
"Pendahuluan: Perkembangan dan Kesudahan Kerajaan Dolog Silou di Simalungun," dalam E.L. Damanik (ed.), Kerajaan Dolog Silou: Silsilah, Perkembangan dan Kesudahannya. Medan: Simetri Institute, hlm. xi-xxx.

Tideman, J. 1936. Hindoe-involved in Noordelijk Batakland. Amsterdam: Uitgave van het Bataksche Instituut No. 23.

Tuuk, H.N. van der. 1861. BatakschNederduitsch Woordenboek. Amsterdam: F. Muller.

Trotter, G. 1994. Royce, Community and Ethnicity. Transactions of the Charles S. Peirce Society, Vol. 30, No. 2, hlm. 231-269.

Vansina, J. 1985. Oral Tradition as History. Madison: University of Wisconsin Press.

Vergouwen, J.C. 1964. The Social Organization and Customary Law of the Toba-Batak of Nothern Sumatra. The Hague: M. Nijhoft.

Veth, P.J. 1877. Het Lanschap Deli. Tijdschrift van de Nederlandsch Aardrijkundig Genootschap II, hlm. 152-170.

Viale, R. 1991. Peregrination of Fernao Mendez Pinto. Paris: La Difference.

Viner, A.C. 1980. The Changing Batak. Malaysian Branch of the Royal Asiatic Society 52, hlm. 84-112.

Vorhooeve, P. 1929. Overzicht van de Volksverhalen der Bataks. Vlissingen: van de Velde. 
Warneck, J. 1925. Sechzig Jahre Batakmission in Sumatra. Berlin: M. Warneck.

Westenberg, C. J. 1892. Aanteekeningen omtrent de Godsdienstige begrippen der KaroBataks. Bijdragen tot de Taal-, Land-en Volkenkunde van de Koninklijk Instituut, 211, hlm. 208253.

. 1897. Verslag van eener reis naar de onafhankelijke Batakalanden ten Noorden van het Tobameer. Tijdschrift van de Nederlandsch Aardrijkundig Genootschap XIV, hlm. 1-112.

Wijngaarden, J.K. 1894. Verslag omtrent de Zending onder KarauBataks over 1893. Mededeelingen van wege het Nederlansch Zendelinggenootschap 38, hlm. 6285 .

Ypes, W.K.H. 1932. Bijdragen tot de Kennis van de Stamverwantschap, de inheemsche Rechtgemeenshappen en het Grondenrecht der Toba en Dairibataks. Gravenhage: Martinus Nijhoff. 
Handep Jurnal Sejarah dan Budaya Vol. 3, No. 1, Desember 2019, hlm. 1-32 